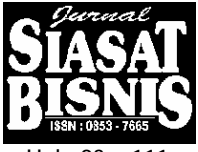

Hal.: $93-111$

\title{
MANAGING PRODUCTIVE PERFORMANCE APPRAISAL: SEBUAH UPAYA MENJAWAB KEBUTUHAN PENILAIAN KINERJA KARYAWAN YANG BEBAS KKN
}

\author{
Sri Dwi Ari Ambarwati \\ Fakultas Ekonomi \\ Universitas Pembangunan Nasional "Veteran"
}

\begin{abstract}
Reviewing employee's performance is always "a nettlesome project" and it's becoming even more so. Performance review typically draw a less than favorable response from employees, and for managers the process is often considered time consuming and feel uncomfortable grading their staff. However, performance review must did by all organization because it will be useful to rise organization performance. This paper will explain some tip how to create an appraisal process that is beneficial and productive, such as develop a performance management process, design spesific and relevan appraisal, promote 360-degree model and how do staff member use their time to achieve organization's objectives. This paper divided into six section including describe general concept of performance appraisal, what's the standard and criteria in appraisal process to guide reviewer and employees, how employed a productive performance appraisal in organization, new way in performance appraisal is use of time and all discussion will be concluded in the last section.
\end{abstract}

Key word: productives appraisal, 360-degree feedback, use of time

PENDAHULUAN

Keberhasilan sebuah organisasi dalam mencapai visi dan misi sangat tergantung dari kualitas Sumber Daya Manusia yang dimiliki. Kualitas Sumber Daya Manusia tersebut dapat ditunjukkan oleh kompetensi, skills, dan kemampuan karyawan dalam menciptakan kualitas kerja yang professional dalam membangun sebuah teamwork dalam organisasi. Sehingga ada kemungkinan dalam organisasi terdapat dua jenis karyawan yang berkualitas dan kurang berkualitas, yang dapat dilihat dari kinerja dan keefektifan mereka dalam melaksanakan tugas. Untuk mengetahui bagaimana keefektifan sumber daya manusia dalam organisasi maka perlu dilakukan suatu evaluasi yang dapat digunakan sebagai dasar penilaian kinerja karyawan dan pimpinan dalam usaha mencapai visi dan misi organisasi.

Penilaian kinerja juga dapat digunakan sebagai dasar kompetensi organisasional, sebagai dasar membuat perencanaan dan dapat memotret "kekurangan" dari kinerja organisasi secara keseluruhan, sehingga penilaian tersebut seharusnya dilakukan baik untuk karyawan maupun pimpinan. Pada era global yang menghadapkan organisasi pada persaingan bisnis yang ketat, penilaian kinerja harus lebih bersifat agregat atau menyeluruh 
meliputi setiap anggota organisasi yang ada. Pandangan klasik yang menganggap bahwa penilaian hanya pantas untuk bawahan saja harus ditinggalkan dan proses penilaian harus dijalankan sebagai sesuatu yang memberikan outcomes bagi organisasi.

Meskipun penilaian kinerja sangat penting untuk dilakukan, bagi beberapa organisasi, kata "performance review" masih mendapat tanggapan yang negatif dan dianggap sebagai suatu aktivitas yang merugikan. Untuk pimpinan, proses penilaian sering mempertimbangkan pemakaian waktu dan beberapa perasaan yang tidak menyenangkan dalam mengevaluasi staff mereka. Sedangkan bagi karyawan ada semacam ketakutan untuk menerima umpan balik yang negatif dari pimpinan mereka (Messmer, Max: 2000). Mengevaluasi kinerja karyawan maupun pimpinan adalah suatu kegiatan yang cenderung melukai hati (nettlesome project) dan hal ini menjadi lebih kompleks karena indikator yang dapat dinilai terdiri dari berbagai faktor fisik maupun psikis yang sulit diukur. Proses penilaian kinerja yang rasional dan obyektif perlu diperjuangkan karena menyangkut masalah pribadi/hubungan antar pribadi, perasaan tidak tega untuk menilai secara benar dan juga dipengaruhi oleh politik organisasi yang berkembang saat itu. Hal itu dapat menjadi penghalang pencapaian proses evaluasi kinerja yang bersih dan obyektif.

Berdasarkan fenomena yang ada di negara kita, yaitu masih banyaknya praktek KKN (Korupsi, Kolusi dan Nepotisme) dalam sebuah organisasi maka harus dirumuskan sebuah proses penilaian kinerja yang dapat mengubah pola orientasi organisasi untuk melakukan praktek KKN itu. Proses penilaian yang produktif, bersih, rasional, dan obyektif harus dikembangkan secara terus-menerus sehingga hasil evaluasi dapat digunakan untuk menghargai atau menghukum pihak yang dievaluasi. Bagi individu yang dinilai berkinerja tinggi, akan dipromosikan dan diberi penghargaan yang sesuai seperti pemberian reward, kompensasi dan promosi karir. Sedangkan individu yang berkinerja buruk akan diberi pengarahan dan sanksi dengan tujuan untuk meningkatkan kinerja mereka. Dengan demikian sedikit-demi sedikit dapat mengurangi praktek KKN dalam hal peningkatan jenjang karir, promosi jabatan, kompensasi, upah dan pengembangan individu dalam lingkungan kerja dengan mendasarkan criteria pada hasil evaluasi tersebut

Meskipun demikian, penghapusan perilaku KKN itu masih menghadapi banyak hambatan yang ditimbulkan oleh politik organisasi yang bersangkutan. Kadang kala masih ada organisasi yang menikmati manfaat adanya KKN dan merasa takut apabila KKN dihapuskan dapat mengubah mekanisme yang sudah ada. Meskipun penilaian kinerja sudah dijalankan, prosesnya masih tetap saja berbau KKN, misalnya penilaian yang masih mendasarkan pada sikap like and dislike tanpa memperdulikan 
prestasi yang telah dihasilkan oleh pihak yang dinilai. Oleh karena itu perlu diperhatikan dalam pemilihan program penilaian kinerja yang terbaik dan akurat sehingga program penilaian yang dipilih akan mampu mengubah pola perilaku KKN yang ada pada organisasi-organisasi di Indonesia.

Penilaian kinerja yang selama ini sudah banyak diterapkan dalam organisasi sebagai upaya untuk memperbaiki system lama yaitu penilaian berdasarkan senioritas, seperti Merit System yaitu penilaian kinerja berdasarkan prestasi kerja karyawan, sampai saat ini masih belum dapat mengoptimalkan penilaian kinerja yang obyektif. Khususnya di Indonesia, penilaian kinerja berdasarkan prestasi kerja sangat sulit untuk diterapkan secara nyata karena banyak anggota organisasi yang merasa terancam kedudukannya, jabatannya, maupun kesejahteraannya (status quo) apabila penilaian kinerja didasarkan atas prestasi kerja. Sehingga system penilaian kinerja merit system seringkali menimbulkan konflik antar anggota organisasi itu sendiri karena mereka belum bisa melepaskan budaya senioritas atau KKN yang dianggap menguntungkan.

Berdasarkan permasalahan diatas, maka dalam tulisan ini penulis mencoba mengemukakan beberapa alternatif cara untuk mengevaluasi kinerja organisasional yang lebih produktif sehingga proses penilaian kinerja dapat berjalan dengan lebih obyektif, rasional dan akurat. Diantaranya proses penilaian model $360^{\circ}$ yaitu proses penilaian kinerja yang mendapatkan feedback dari pimpinan/eksekutif dan kawan sebaya/peer, model balance scorecard of performance dan penilaian berdasar use of time. Perubahan proses penilaian tersebut perlu terus-menerus dikembangkan untuk mencapai kinerja organisasi yang tinggi berdasarkan konsep team work.

\section{KONSEP PENILAIAN KINERJA}

Hakekat penilaian kinerja sebagai kegiatan Manajemen Sumber Daya Manusia adalah proses pengamatan (observasi) terhadap pelaksanaan pekerjaan oleh seorang pekerja. Dari hasil pengamatan tersebut dilakukan pengukuran yang dinyatakan dalam bentuk penetapan keputusan mengenai keberhasilan atau kegagalannya dalam bekerja (Nawawi, Hadari, 2000). Penilaian tersebut dilakukan sebagai proses mengungkapkan kegiatan manusia dalam bekerja yang sifat dan bobotnya ditekankan sebagai perilaku manusia sebagai perwujudan dimensi kemanusiaan, sehingga pengukuran yang dilakukan bukan secara matematis yang sifatnya pasti. Kesulitan melakukan penilaian secara matematis disebabkan oleh banyaknya aspek psikis yang tidak dapat dinyatakan dalam bentuk angka, diantaranya aspek emosionalitas pekerja sebagai manusia.

Aspek psikis dalam penilaian sangat mudah menimbulkan perasaan tersinggung karena sifat sensitif manusia, bilamana hasil evaluasi tidak 
sesuai dengan usaha yang telah dilakukannya/tidak obyektif. Penilaian kinerja yang kegiatannya sering menyentuh kelemahan atau kekurangan individu, seringkali dirasakan sebagai pelanggaran hak asasi. Oleh karena itu proses penilaian harus dilakukan dengan sangat hati-hati dengan mendapatkan feedback baik dari pimpinan serta kawan sebaya (peer).

Hasil penilaian yang menyatakan kelemahan atau kekurangan pekerja, maupun prestasi atau kelebihannya, pada dasarnya merupakan informasi yang sangat berharga bagi para pimpinan. Hasil evaluasi tersebut tidak dapat dilepaskan kaitannya dengan keputusan-keputusan dan kebijakan-kebijakan pimpinan, khususnya atasan langsung pekerja yang dievaluasi. Keberhasilan yang perlu dipertahankan dan bahkan ditingkatkan atau sebaliknya kegagalan yang harus diperbaiki, sebagian diantaranya disebabkan oleh keputusan yang tepat atau tidak tepat dari pimpinan. Oleh karena itu setiap pimpinan harus dapat menempatkan hakekat penilaian kinerja sebagai kegiatan yang dapat memberikan informasi sebagai umpan balik (feedback). Informasi-informasi tersebut akan berguna juga bagi pimpinan untuk mempertahankan atau memperbaiki keputusan atau kebijakannya.

Umpan balik dari hasil penilaian hanya akan berguna jika dalam mendiagnose pelaksanaan pekerjaan dan menemukan masalah-masalah, juga mampu mengungkapkan sebab-sebabnya. Penilaian kinerja hanya akan bermanfaat jika pimpinan/top manajer memberikan perhatian yang serius terhadap sebab-sebab terjadinya kegagalan pelaksanaan pekerjaan dengan berusaha untuk memperbaikinya. Perhatian dan usaha perbaikan yang ditujukan bagi pekerja harus bersifat bantuan karena motivasi untuk memperbaiki kinerja harus datang dari pekerja itu sendiri. Untuk itu pekerja harus mengetahui kelebihan dan kekurangannya beserta sebab-sebabnya agar dapat melakukan tindakan yang tepat dalam melakukan perbaikan.

Salah satu tantangan yang harus dihadapi adalah untuk merestrukturisasi dan mengelola proses penilaian kinerja yang fair dan akurat. Tetapi dengan sedikit penelitian dan penerapan yang hati-hati akan dapat diciptakan program penilaian yang dapat memuaskan kebutuhan baik manajer dan staff. Manfaat penilaian kinerja adalah: menjaga staff untuk tetap terfokus pada tujuan dan sasaran organisasi, memberikan training dan pengembangan yang diperlukan bagi pekerja, memotivasi staff akuntansi untuk meningkatkan ketrampilan dan job knowledge untuk memberikan kontribusi yang lebih besar bagi organisasi, menyediakan sebuah tujuan dan dasar pertahanan secara legal sebagai kunci bagi keputusan sumber daya manusia, meliputi promosi dan kenaikan gaji, dan memecahkan kembali kesulitan dalam hubungan antar pekerja (Messmer, Max: 2000).

Dalam penilaian kinerja menentukan siapa yang harus melakukan evaluasi adalah merupakan hal terpenting. Kuantitas dan kualitas pengetahuan tugas mungkin bervariasi sesuai dengan tingkat organisasi, demikian juga 
kedekatan pekerja dengan pemberi rating dalam evaluasi. Penentuan tentang siapa yang akan melakukan evaluasi dianggap sebagai hal penting karena tidak ada seorang pun dalam organisasi yang memiliki informasi terlengkap yang dapat digunakan sebagai dasar penilaian. Misalnya, seorang penyelia (pimpinan) mempunyai akses yang lebih besar untuk informasi hasil dan kinerja penjualan dibandingkan dengan karyawan atau pelanggan (S. Randall: 1999). Sedangkan bawahan (karyawan) mungkin mempunyai informasi tentang hubungan antara pimpinan dan bawahannya, atau informasi tentang kinerja rekan kerjanya. Oleh karena itu pihak yang berhak melakukan penilaian kinerja adalah semua anggota organisasi agar terjadi shares information yang berguna dalam proses evaluasi.

Dengan melibatkan beraneka ragam pemberi rating atau penilai yaitu penyelia, bawahan, rekan sejawat dan diri sendiri dalam proses penilaian dapat menghantarkan pihak ternilai untuk mengetahui sebabsebab yang mempengaruhi kinerjanya dan dapat memberi feedback bagi pengembangan organisasi. Pendekatan itu sering disebut proses penilaian 360-degree yaitu proses penilaian yang diharapkan dapat menghasilkan sesuatu yang berguna bagi organisasi.

Menurut Randall (1999) terdapat beberapa cara penilaian kinerja yang secara strategis dapat mengungkap kinerja bawahan secara lebih komprehensif. Berbagai penilaian kinerja tersebut adalah :

1. Penilaian Atasan,

Istilah atasan yang mengacu pada pimpinan langsung bawahan yang sedang dievaluasi. Banyak perusahaan/ organisasi yang menganggap atasan lebih mengetahui pekerjaan dan kinerja bawahan daripada siapapun dan karena itu organisasi memberikan seluruh tanggung jawab penilaian kepada atasan.

2. Penilaian Diri Sendiri,

Penggunanaan penilaian diri sendiri, khususnya melalui partisipasi bawahan dalam menetapkan tujuan, dipopulerkan sebagai komponen management by objectives (MBO). Bawahan yang berpartisipasi dalam proses evaluasi mungkin akan lebih terlibat dan punya komitmen pada tujuan. Partisipasi bawahan mungkin juga akan membantu menjelaskan peran karyawan dan mengurangi konflik peran.

3. Penilaian Rekan sejawat atau anggota tim

Penggunaan penilaian anggota tim agaknya meningkat saat memasuki abad ke-21 ditinjau dari focus korporasi Amerika yaitu partisipasi karyawan, kerjasama tim dan pemberian wewenang. Salah satu alasannya adalah bahwa penilaian rekan sejawat terlihat sebagai alat prediksi kinerja masa mendatang yang bermanfaat.

4. Penilaian Ke Atas atau Terbalik 
Yaitu penilaian yang dilakukan oleh karyawan untuk menilai manajemen organisasi, bagaimana opini karyawan tentang manajemen organisasi. Meskipun karyawan tidak mempunyai akses ke informasi mengenai seluruh dimensi kinerja penyeliaan, mereka sering mempunyai akses ke informasi mengenai interaksi penyelia-bawahan.

5. Penilaian Pelanggan

Adalah penilaian yang dilakukan oleh pelanggan untuk menilai kinerja karyawan dan pimpinan organisasi melalui kualitas pelayanan yang diberikan dan kualitas produk yang ditawarkan oleh organisasi.

Untuk mendapatkan outcomes sesuai yang diharapkan dengan dilakukannya penilaian kinerja maka organisasi sebaiknya mulai menerapkan proses penilaian 360-degree. Proses penilaian itu dilaksanakan dengan mengevaluasi diri sendiri dan menggabungkan seluruh informasi atau feedback baik dari penyelia, rekan sejawat atau pelanggan. Semua pihak yang menjadi anggota dalam organisasi dilibatkan dalam memberi informasi yang sangat diperlukan dalam penilaian. Pandangan klasik yang menganggap bahwa yang berhak menilai hanya pimpinan saja harus segera ditinggalkan dan berusaha menerapkan penilaian kinerja menurut paradigma baru.

Begitu juga untuk kasus di Indonesia, sebaiknya mulai menerapkan penilaian kinerja seperti yang dijelaskan diatas. Meskipun masih banyak kendala yang dihadapi oleh organisasi seperti masih terperangkap untuk mempertahankan pola lama, mitos-mitos penilaian dan dipengaruhi politik organisasi, namun apabila terus mengupayakan perbaikan penilaian tersebut akan memperoleh manfaat yang lebih besar. Manfaat yang akan diperoleh apabila organisasi di Indonesia menerapkan penilaian 360-degree adalah semua penilaian yang diberikan oleh manajer, bawahan, rekan sejawat, diri sendiri dan pelanggan dapat memberikan hasil penilaian yang sangat akurat dan obyektif mengenai kinerja pihak yang dinilai.

Semua informasi yang diperoleh dari berbagai sumber (manajer, diri sendiri, rekan sejawat dan pelanggan) dapat menambah keakuratan dan keobyektifan dalam melakukan penilaian kinerja .Sehingga jika diterapkan di Indonesia yang masih berbau KKN dalam proses penilaian kinerja, metode penilaian 360-degree akan sangat membantu dalam usaha memberantas perilaku KKN tersebut. Namun, hal itu hanya dapat terwujud jika hasil penilaian tersebut benar-benar digunakan sebagai dasar pertimbangan untuk melakukan tindak lanjut bagi kegiatan manajemen seperti promosi, jenjang karir, kenaikan upah dan gaji, dan tidak hanya sebagai formalitas belaka tanpa ada tindak lanjutnya. 


\section{STANDAR PEKERJAAN DAN KRITERIA DALAM PENILAIAN}

Kegiatan Manajemen SDM yang efektif harus dimulai dengan menetapkan standar pekerjaan yang akurat, baik untuk pekerja sebagai individu maupun kelompok/tim. Sumber utamanya adalah hasil analisis pekerjaan berupa deskripsi/spesifikasi pekerjaan. Dalam keadaan yang terus berkembang maka standar pekerjaan juga harus dikembangkan sesuai dengan keperluan atau jika diperlukan. Standar pekerjaan harus mencakup tiga informasi pokok sebagai kriteria untuk melakukan penilaian kinerja yaitu informasi tentang apa tugas yang harus dikerjakan oleh seorang pekerja, termasuk supervisor/pimpinan, informasi tentang bagaimana cara terbaik dalam melaksanakan tugas tersebut, dan informasi tentang hasil maksimal yang seharusnya dicapai dalam melaksanakan tugas dengan cara tersebut.

Dari ketiga informasi utama itu penilaian kinerja difokuskan pada bagaimana cara terbaik dalam melaksanakan tugas-tugas. Kriteria di dalam standar pekerjaan harus dibuat secara tertulis agar pimpinan dan pekerja dapat mengetahui apa yang diharapkan organisasi dari dirinya dalam bekerja. Dengan demikian pekerja dapat memperoleh kepuasan dalam bekerja dan yang berprestasi akan merasa dihargai secara fair.

Kriteria dalam standar pekerjaan mencakup aspek pengukuran yang bersifat kuantitatif dan kualitatif. Aspek kuantitatif bersifat empiris, dapat diamati atau ditransformasikan dalam bentuk bilangan atau angka. Aspek kualitatif bersifat konseptual, diinterpretasikan dari gejala yang dapat diamati.

Tabel 1.

Aspek-Aspek Standar Pekerjaan

\begin{tabular}{|l|l|}
\hline \multicolumn{1}{|c|}{ Aspek Kuantitatif } & \multicolumn{1}{c|}{ Aspek Kualitatif } \\
\hline$\square$ Proses kerja dan kondisi pekerjaan. & Ketepatan kerja dan kualitas pekerjaan \\
$\square$ Waktu yang digunakan dalam pekerjaan & $\square$ Tingkat kemampuan dalam bekerja \\
(use of time) & $\square$ Kemampuan menganalisis \\
$\square$ Jumlah kesalahan dalam bekerja & $\square$ informasi, memakai peralatan \\
$\square$ Jumlah dan jenis pelayanan dalam bekerja & $\square$ Kemampuan mengevaluasi keluhan \\
& $\square$ Penelitian pasar \\
\hline
\end{tabular}

Sumber: Nawawi, Hadari: 2000

Untuk pekerja yang melaksanakan proses produksi, bobot aspek kuantitatif lebih besar dari aspek kualitatif. Sebaliknya pada pekerjaan manajerial aspek kualitatif lebih besar dari aspek kuantitatif. Pendapat lain menurut Max Messmer: 2000, ketika memulai proses perubahan atau memperkenalkan program evaluasi kinerja, diperlukann penentuan standar 
pekerjaan yang spesifik. Jika sudah mendapatkan kriteria apa yang akan dinilai dan syarat-syarat yang menjadi dasar penilaian untuk masing-masing posisi, barulah proses penilaian dapat dirumuskan dengan baik. Setelah dijalankan untuk beberapa waktu maka suatu saat perlu direevaluasi kembali untuk menyesuaikan dengan keadaan saat ini. Langkah kedua adalah memilih format penilaian. Membuat dan menyusun rencana penilaian agar dapat diterapkan secara nyata dan mampu menjawab permasalahan sehubungan dengan penilaian serta dapat mencapai tujuan yang ditetapkan dengan dilakukannya program penilaian itu. Program penilaian kinerja yang cacat/salah akan menghasilkan evaluasi yang salah juga, sehingga dapat mempengaruhi produktivitas baik pekerja maupun pimpinan, misal departemen akuntansi atau keuangan secara umum.

Elemen dari penilaian kinerja yang baik (Messmer, Max; 2000) adalah: menyusun tujuan yang akan dilakukan oleh pekerja maupun pimpinan pada akhir penilaian, daftar kompetensi khusus atau ketrampilan yang akan diukur dengan contoh dari perilaku yang berhasil/ prestasi, skala peringkat atau rating yang tepat untuk organisasi, ruang untuk pekerja dalam melakukan penilaian untuk diri sendiri, ruang untuk penilaian supervisor/pimpinan, ruang untuk kegiatan khusus dari pimpinan tentang kinerja pekerjanya, menganjurkan pengembangan pekerja/karyawan, tujuan untuk menyesuaikan dengan tanggal penilaian berikutnya.

Menurut Randall S. Schuller;1999 ada jenis-jenis kriteria kinerja yang dapat membantu penilai dalam menilai kinerja organisasi, yaitu; kriteria berdasarkan sifat, memusatkan diri pada karakteristik pribadi seorang karyawan. Loyalitas, keandalan, kemampuan berkomunikasi dan ketrampilan memimpin merupakan sifat yang sering dinilai selama proses penilaian. Kriteria berdasarkan perilaku, terfokus pada bagaimana pekerjaan dilaksanakan. Kriteria semacam ini penting sekali bagi pekerjaan yang membutuhkan hubungan antar personal. Dan kriteria berdasarkan hasil, terfokus pada apa yang telah dicapai atau dihasilkan. Kriteria ini tepat jika perusahaan tidak perduli bagaimana hasil dicapai, tapi tidak tepat untuk semua pekerjaan.

Penilaian kinerja yang mendasarkan pada beberapa kriteria seperti sifat atau karakteristik individu, bagaimana pekerjaan dilakukan/perilaku, dan apa yang telah dicapai dapat memberikan informasi kepada pihak penilai mengenai kinerja organisasinya dengan lebih baik dan jelas. Apabila hal itu diterapkan di Indonesia, maka kegiatan penilaian yang berbau KKN dapat dikurangi karena kriteria yang dijadikan dasar penilaian sudah jelas. Sehingga program promosi, karir dan pemberian reward dapat didistribusikan kepada orang-orang yang tepat berdasarkan hasil penilaian yang dilakukan berdasarkan kriteria-kriteria yang ada. 


\section{ISU YANG PERLU DIPERTIMBANGKAN DALAM MEMILIH SISTEM EVALUASI KINERJA}

Ketika penilaian sudah tidak fair, akurat dan tepat waktu, maka penilaian tersebut gagal untuk mendapatkan pekerja yang sangat bagus dalam bekerja atau berkualitas, gagal untuk menyediakan dorongan dan pedoman untuk pekerja dalam garis batas dan gagal untuk memberi feedback kepada pekerja yang tidak memenuhi syarat dalam bekerja (Joinson, Clara: March 2001). Oleh karena itu organisasi perlu menetapkan sistem penilaian kinerja yang mendekati kriteria fair, akurat dan tepat waktu sesuai dengan keinginan baik karyawan maupun pimpinan, sehingga kedua pihak mendapatkan kepuasan dalam bekerja dan akhirnya dapat meningkatkan produktivitas mereka sehubungan dengan pencapaian visi dan misi organisasi dimana mereka bekerja.

Tidak ada masalah, sistem penilaian macam apa yang akan digunakan dalam sebuah organisasi. Ada beberapa isu yang dapat digunakan sebagai bahan pertimbangan ketika akan menetapkan elemen dari sistem penilaian kinerja meliputi (Joinson, Clara; 2001):

\section{Keep It Simple}

Beberapa ahli menganjurkan untuk menjaga agar proses dan kertas kerja penilaian dibuat sesederhana mungkin, sehingga system penilaian yang baru tersebut secara efektif dapat sesuai dengan tujuan sebenarnya yaitu untuk mengkomunikasikan kepada pekerja status dari kinerja mereka.

2. Setting Objectives

Ada tiga criteria dalam penilaian yaitu:

- Flexibility, dalam menetapkan kriteria penilaian harus fleksibel sehingga dapat digunakan untuk mengukur kinerja pada berbagai posisi dalam organisasi.

- Employee involvement, para pimpinan harus dapat bekerjasama dengan karyawannya yang sudah bekerja dan mengambil umpan balik dari mereka dalam usaha untuk mengembangkan standar yang realistis. Para pimpinan dianjurkan untuk melibatkan pekerja dalam menetapkan standar dan tujuan penilaian, karena pekerja juga dapat memainkan peranan dalam mengevaluasi kinerja mereka.

- Clear and objective objectives, dalam organisasi sangat penting untuk membuat tujuan sebersih mungkin, seobyektif mungkin dan dapat diukur (clear and measurable). Sehingga perusahaan harus mulai memberi perhatian lebih pada bagaimana mereka mengharapkan pekerja dapat menjalankan tugas sesuai dengan tujuan organisasi.

3. Timing 
Beberapa perusahaan sudah mengalami perubahan penilaian dari hari jadi/peringatan pekerja secara individual atau model ulang tahun (individual anniversary dates) menjadi penilaian pekerja secara keseluruhan dalam waktu satu hari atau system titik focus (single focal date). Tetapi ada beberapa perusahaan yang masih suka cara lama yaitu berdasarkan hari jadi pekerja secara individual karena focal dates appraisal menempatkan beban yang terlalu besar pada pimpinan/manajer.

4. Reviewing Review Result.

Hasil penilaian harus diumumkan atau diinformasikan sehingga pekerja tahu seberapa besar kontribusi yang sudah mereka berikan untuk organisasi dan dapat melakukan perbaikan diri di kemudian hari.

Meskipun demikian sistem penilaian kinerja memiliki kekuatan dan kelemahan yang berbeda-beda, sehingga beberapa isu yang disebutkan di atas diharapkan mampu membantu organisasi untuk menetapkan sistem penilaian yang lebih baik. Suatu program evaluasi akan lebih berguna apabila tujuan yang akan dicapai dengan dilakukannya evaluasi kinerja tersebut jelas dan dikomunikasikan secara gamblang kepada seluruh pekerja baik pimpinan maupun bawahan. Dengan mempertimbangkan antara lain isu yang sudah disebutkan di atas diharapkan penilaian yang dilakukan lebih menghasilkan sesuatu yang bergunan dan adanya follow up di kemudian hari. Saat ini ada beberapa metode yang sangat popular digunakan dalam menilai kinerja, diantaranya (Mesmer, Max;2000):

1. Essay Appraisals, dalam program ini pimpinan menyediakan analisis tertulis dari kinerja karyawan selama periode penilaian. Supervisor biasanya melengkapi formulir yang meminta deskripsi beberapa aspek dari kerja individu. Metode ini sederhana dan mudah bagi administrasi tapi keefektifannya tergantung dari ketrampilan menulis pihak penilai/ evaluator.

2. Management by Objectives, saat ini banyak yang mendasarkan struktur penilaian pada MBO. Secara khusus, pekerja dan pemimpin bertemu pada permulaan periode penilaian dan menyusun kalimat yang menyajikan target yang realistis, spesifik dan measurable. Tetapi MBO tidak akan berjalan baik untuk pekerja yang mempunyai sedikit keleluasaan dalam melaksanakan pekerjaan mereka.

3. Job rating checklist, departemen SDM menyediakan bagi tiap penilai pernyataan yang sudah disiapkan atau pertanyaan yang berhubungan dengan aspek spesifik dari kinerja yang biasanya dijawab dengan "ya" dan "tidak". Tetapi metode ini kurang ideal jika deskripsi pekerjaan departemen sering berubah-ubah.

4. Forced Choice, metode ini secara umum muncul dalam dua bentuk: sepasang pernyataan dan rangking yang dibuat dengan terpaksa. Penilai diperbolehkan memilih antara dua pernyataan yang terbaik yang mendeskripsikan kinerja karyawan. 
5. Behaviorally Anchored Rating Scala (BARS), skala ini biasanya berbentuk peringkat perilaku dari sangat buruk ke sangat hebat dan mengkaitkan peringkat ini dengan tindakan spesifik atau 'anchor statement". Keefektifan metode ini tergantung pada keakuratan dan ketepatan dari pernyataan ini.

6. Multi-Rater Assessments (360-degree), metode yang relatif baru, dan metode penilaian ini mendapatkan informasi dari supervisor, diri sendiri, teman sekerja, dan kadang-kadang orang dari luar perusahaan.

Apapun metode atau program penilaian kinerja yang akan dipilih, hanya akan berhasil jika tujuan dan seluk beluk mekanis dari system telah dikomunikasikan secara jelas kepada seluruh pekerja. Ketika akan memperkenalkan rencana penilaian kinerja, seharusnya memberitahu seluruh staff sasaran keseluruhan program: bagaimana pekerja akan bermanfaat bagi organisasi, bagaimana kriteria penilaian yang akan dikembangkan, dan lamanya periode penilaian. Juga penting untuk mengijinkan pekerja mengetahui bagaimana hasil penilaian kinerja yang akan berkaitan dengan bonus, kenaikan gaji dan aktivitas lain dan pilihan apa yang tersedia sebagai alternatif jika mereka tidak setuju dengan hasil penilaian. Informasi pimpinan tentang beberapa training yang akan disediakan untuk membantu pimpinan mengimplementasikan program penilaian tersebut.

Untuk Indonesia yang masih sarat adanya KKN, pengimplementasian salah satu atau kombinasi dari keenam metode penilaian tersebut adalah sangat penting dan relevan. Melalui pengimplementasian metode itu, pihak penilai dapat mengetahui skala/rangking yang menggambarkan peringkat kinerja karyawan dan informasi-informasi yang relevan dengan proses penilaian kinerja dengan lebih tepat dan akurat. Keakuratan dan ketepatan informasi itu dapat dijadikan sebagai dasar pertimbangan dalam penilaian sehingga dapat dihasilkan penilaian yang bersih, akurat dan obyektif sebagai manifestasi dari prestasi yang dicapai karyawan. Dengan demikian pola perilaku KKN, khususnya di Indonesia dapat dikurangi sedikit demi sedikit.

\section{BAGAIMANA MENJALANKAN PENILAIAN KINERJA YANG PRODUKTIF}

Ketika mendengar kata "penilaian kinerja" bagi pimpinan ekspresi yang mungkin muncul adalah keluh kesah dan pikiran yang frustrasi. Sementara itu bagi sebagian pekerja reaksi yang muncul adalah kengerian. Mengapa penilaiankinerja membangkitkan reaksi negatif? Orang sering berkata bahwa penilaian tradisional adalah "a lot of work" tanpa "a lot of value". Tetapi ini tidak harus diambil sebagai suatu cara. Penilaian dapat menjadi alat yang berguna untuk pimpinan dan pekerja jika penilaian tersebut dapat diadakan/dijalankan, digunakan dan distruktur sebagaimana mestinya. 
Hampir setiap pimpinan tidak senang menerima dan memberikan penilaian,tapi mereka mengakui bahwa penilaian merupakan fakta dalam kehidupan organisasi. Karena pentingnya aturan main dalam penilaian karir individual dan kinerja organisasi maka perhatian besar dicurahkan untuk mengerti proses penilaian. Saat ini aktivitas dipusatkan pada proses perbaikan mental pimpinan yang membuat penilaian, apa yang ada di benak pimpinan dan bagaimana mereka bekerja. Banyak kalangan eksekutif yang membuat penilaian masih dipengaruhi oleh faktor emosi. Penilaian kinerja yang akurat tak mungkin dapat dicapai apabila benak pimpinan masih dipengaruhi oleh subyektivitas dan politik organisasi. Pimpinan tidak tertarik pada keakuratan penilaian tetapi lebih tertarik pada penilaian yang tetap menjaga dan meningkatkan kinerja masa depan bawahannya. Pimpinan kadang-kadang memberikan penilaian yang lebih baik dari yang semestinya terhadap bawahannya agar tidak terjadi konfrontasi diantara mereka. Adanya berbagai pertimbangan psikologis seperti itu yang menjadikan penilaian menjadi tidak menarik dan kurang memberikan motivasi bagi sebagian pekerja yang berprestasi. Fakta menyebutkan dibalik keobyektifan dan kerasionalan penilaian kinerja, pimpinan menggunakan manipulasi dengan cara yang disengaja dan sistematis (Longenecker O. Clinton, et all; 1987).

Penilaian pimpinan biasanya uncertain, unstructured, dan sulit didefinisikan padahal penilaian untuk pimpinan adalah kegiatan paling penting di dalam organisasi. Ada beberapa mitos yang relevan yang berisi paradox penilaian pimpinan, misalnya seorang pimpinan yang merasa tidak perlu untuk dinilai. Mitos-mitos itu tidak hanya akan menghalangi pimpinan dalam mengerjakan pekerjaan mereka tapi juga dapat mempersulit pengembangan profesinya. Oleh karena itu mitos-mitos itu perlu dihilangkan karena bagaimanapun juga hasil penilaian itu sangat penting sebagai feedback bagi dirinya dan organisasi. Sehingga dia sebagai pekerja/pimpinan mengetahui apa yang diharapkan organisasi dari diri mereka atau kontribusi apa yang harus mereka berikan bagi kemajuan organisasi. Untuk itu sebaiknya program penilaian kinerja dilaksanakan secara teratur sebagai sesuatu yang mempunyai konsekuensi tertentu bukan hanya sebagai upacara ceremonial.

Penilaian kinerja bukan merupakan kegiatan kontrol atau pengawasan, meskipun hasilnya dapat dipergunakan untuk melakukan tindak lanjut yang menunjang kegiatan manajemen tersebut. Kegiatan penilaian kinerja harus dilakukan secara rinci mengenai beberapa aspek dalam bekerja untuk mengetahui relevansinya dengan tujuan bisnis organisasi/perusahan. Oleh karena itu metode atau instrumen yang digunakan dalam penilaian harus memenuhi persyaratan, agar dapat mengungkapkan informasi tentang pekerja dan pelaksanaan pekerjaan yang menjadi tugas 
pokoknya. Persyaratan system penilaian yang efektif menurut Hadari Nawawi: 2000 adalah persyaratan ilmiah atau persyaratan formal: relevansi, sensitivitas, dan reliabilitas; persyaratan operasional: akseptabel, dan praktis.

Dari uraian diatas jelas bahwa penilaian kinerja merupakan kegiatan MSDM yang berhubungan dengan kepentingan, hak dan martabat atau kehormatan seorang pekerja sebagai individu. Untuk menghindari kesulitan dari sisi hukum maka penilaian kinerja harus dilakukan secara cermat dan hati-hati dengan memperhatikan isu yang sudah dijelaskan diatas sebelum memilih system penilaian kinerja.

Menurut artikel Julia McCarthy:2000, ada beberapa perangkap atau pitfalls dari penilaian kinerja secara tradisional yang umum terjadi dan beberapa tips untuk membuat sebuah proses penilaian yang akan bermanfaat dan produktif.

\section{Pitfalls: The Standalone Annual Review}

Pekerja memerlukan feedback untuk memperbaiki kinerja mereka dan mengembangkan ketrampilan yang baru. Menjalankan penilaian kinerja tahunan adalah ide bagus sepanjang hal itu tidak hanya pada waktu pekerja dan pimpinan berdiskusi soal kinerja. Untuk pekerja, annualreview mungkin yang pertama kali ketika mereka belajar tentang masalah penilaian. Sehingga sebaiknya organisasi mengembangkan Performance Management Process atau proses manajemen kinerja secara keseluruhan untuk menghadapi tantangan dalam standalone review. Penilaian tahunan adalah sebuah even, sedangkan proses manajemen kinerja memperkenalkan elemen dari interaksi yang terus menerus antara pimpinan dan pekerja. Tipe proses penilaian ini menyediakan arena untuk berdialog secara lebih teratur antara pimpinan dan pekerja tentang kemajuan pekerja dan beberapa tantangan yang dapat diambil dalam rangka mencapai sasaran tersebut. Pimpinan seharusnya secara terbuka dan teratur memberikan feedback kepada pekerja tentang kinerja mereka secara keseluruhan dan mendiskusikan isu-isu kinerja ketika isu tersebut muncul.

2. Pitfalls: The Generic Appraisal

Tidak semua posisi dalam perusahaan memerlukan ketrampilan atau pengetahuan yang sama. Menggunakan penilaian yang umum (generic) dapat mematikan (demish) nilai dari proses jika pimpinan atau pekerja tidak melihat hubungan langsung dengan pertanggungjawaban pekerjaan pekerja secara harian. Sehingga sebaiknya organisasi membentuk spesific and Relevan Appraisal yaitu penilaian yang lebih berguna untuk kedua belah pihak jika item-item yang dinilai sesuai dengan syarat-syarat dan fungsi esensial dari pekerjaan. Beberapa pimpinan menggunakan deskripsi pekerjaan untuk mengembangkan item penilaian yang relevan. Selain itu mengidentifikasi tujuan-tujuan kunci 
untuk masing-masing pekerja dan memusatkan penilaian pada pencapaian tujuan tersebut. Beberapa perusahaan telah mengubah konsep bisnis mereka menjadi konsep bisnis dari kompetensi inti (core competency), atau job-related abilities, untuk membantu mengidentifikasi item-item yang sangat penting untuk keberhasilan individu dalam pekerjaan khusus. Dengan memusatkan pada isu yang berhubungan dengan pekerjaan khusus, ada sedikit kemungkinan bagi penilai dipengaruhi oleh informasi yang tidak relevan seperti kepribadian dan latar belakang pribadi.

3. Pitfals: One -sided Appraisal

Penilaian yang hanya satu sisi, yaitu pimpinan yang menilai pekerjanya biasanya menghasilkan perbaikan yang dikeluh kesahkan oleh pimpinan. Dalam beberapa kasus, hal ini disebabkan karena pekerja tidak setuju dengan evaluasi, dalam kasus lain, pekerja kemungkinan tidak mengerti peringkat atau bagaimana untuk meraih hasil yang diinginkan organisasi. Sehingga sebaiknya organisasi menerapkan Two-way Dialogue or 360- degree Feedback yaitu proses penilaian oleh dirinya sendiri. Pendekatan ini dapat membuat forum untuk membuka dialog dan cukup sederhana untuk diterapkan. Pekerja yang mempunyai kesempatan untuk menilai kinerja dirinya sendiri sering memajukan solusi yang kreatif yang tidak akan ditemukan dalam diskusi penilaian satu sisi. Peringkat ganda atau umpan balik 360degree, mengumpulkan input dari orang-orang pokok yang sering berhubungan dengan pekerja seperti pimpinan/bos, diri sendiri, kawan sejawat, dan laporan langsung dari pekerja (direct report). Sedangkan jika yang dinilai adalah pimpinan maka feedback datang dari para penyumbang dana organisasi. Umpan balik 360-degree dapat menyediakan informasi yang berguna tentang kesempatan pengembangan pekerja.

Dengan melakukan perubahan dalam proses penialaian kinerja, kita menemukan bahwa suatu proses penilaian kinerja yang tadinya menakutkan dapat menjadi pengalaman yang positif semua pihak yang terlibat. Konsep penilaian 360-degree merupakan model yang sederhana dan mudah diterapkan, disini pekerja menilai diri sendiri dan menerima feedback dari pekerja lain dan anggota organisasi. Model 360-degree mencoba untuk menggambarkan system keseluruhan-mempertimbangkan seperti input, proses dan outcomes dan menetapkan komponen-komponen dalam system. Model ini mengusulkan bahwa input yang berkualitas, dan ketika diproses dengan efektif akan menghasilkan outcomes yang diinginkan. Hal ini berarti bahwa organisasi harus menyediakan dukungan organisasional untuk input dan proses agar dapat mencapai outcomes yang diinginkan.

Jadi adanya perbedaan reaksi terhadap umpan balik yang diberikan dalam model 360-degree menunjukkan bahwa penilaian diri sendiri dan rekan 
sejawat bisa bermacam-macam sehingga proses tersebut harus menjamin suatu peningkatan kesadaran ternilai tentang persepsi orang lain terhadap mereka dan komitmen memperbaiki bidang-bidang yang ditargetkan. Untuk memastikan proses tersebut benar-benar efektif, organisasi harus menyediakan; pelatihan just in time, menyelenggarakan pengukuran penilaian 360-degree mini, menghargai perbaikan dalam perilaku keja yang diinginkan dan menjamin bahwa ternilai bertanggung jawab untuk melakukan perbaikan yang diperlukan yang akhirnya tercapai outcomes yang diinginkan.

Isu penilaian kinerja yang produktif sangat relevan apabila diterapkan dan dikembangkan di Indonesia berkaitan dengan adanya kompetisi bisnis yang semakin ketat. Dengan menghilangkan perangkap penilaian tradisional dan mengganti dengan penilaian produktif seperti yang disebutkan dalam artikel Julia: 2000 di atas, maka proses penilaian akan lebih akurat dan obyektif sehingga kinerja organisasi dapat meningkat dan outcomes yang sudah ditargetkan dapat tercapai. Sehingga program penilaian yang dilaksanakan di Indonesia benar-benar bersih, obyektif, efektif dan dapat memberikan manfaat bagi anggota organisasi secara keseluruhan (pimpinan dan karyawan) serta memberikan kontribusi yang cukup besar bagi kemajuan organisasi.

Namun, permasalahan penilaian kinerja sampai saat ini masih menjadi isu yang menarik karena banyak organisasi yang belum mampu menerapkan program penilaian kinerja yang sesuai dengan kondisi internal organisasi. Seperti yang kita ketahui bahwa perubahan penilaian kinerja yang lebih baik tentu saja melibatkan perubahan yang signifikan dalam budaya organisasi. Sangat sulit dan membutuhkan waktu lama untuk mengubah pola atau budaya yang sudah melekat dalam diri individu sehingga sulit juga untuk mengubah program penilaian kinerja yang lebih baik.

Apalagi budaya "gotong royong atau kerja sama" yang sering kita dengar, akan dapat menghambat keberhasilan penilaian kinerja yang menuntut keakuratan, ke obyektifan dan kerasionalan. Dengan budaya itu organisasi cenderung akan kembali ke pola lama yang menilai kinerja berdasarkan senioritas, like and dislike, dan KKN.

Program penilaian kinerja juga menghadapi kendala dalam menilai atau mengukur kinerja tim, sehingga penilaian kinerja masih menjadi bahan diskusi sehubungan bagaimana menilai kinerja tim. Penilaian kinerja yang selama ini ada hanya mengukur prestasi secara individual dan belum menemukan ukuran yang tepat untuk mengukur kinerja tim secara keseluruhan. Idealnya harus diupayakan system pengukuran yang didesain untuk mendukung team-based organization. Peran utama sistem penilaian tradisional (senioritas) adalah menaikkan "informasi baik" sedemikian rupa sehingga manajer senior dapat membuat "keputusan baik" yang mengalir ke bawah. 


\section{CARA BARU MENGUKUR KINERJA ORGANISASI: MENGUKUR USE OF TIME}

Bagaimana staff atau pekerja memanfaatkan waktu mereka? Jawaban pertanyaan ini merupakan kunci sukses organisasi dan mengukur pemanfaatan waktu (measure use of time) adalah sebuah peluang dalam mengevaluasi kinerja organisasi.

Waktu adalah penyama (equalizer) yang sangat baik, tua muda, miskin kaya, berpendidikan atau tidak sama-sama menghabiskan waktu 24 jam seharinya. Sehingga bagaimana pimpinan dan karyawan memanfaatkan waktu adalah sebagai penentu bagaimana keberhasilan pimpinan dalam mengelola organisasi. Menggunakan metode ini membantu pimpinan dalam melihat apakah ia mengalokasikan waktu karyawan/staff sudah pada aktivitas dan outcomes yang tepat. Menjelaskan pemanfaatan waktu akan menyediakan wawasan menuju bagaimana organisasi akan dibentuk dan bagaimana kita dapat memperbaiki hasil yang sudah dicapai. Metode pengukuran berdasarkan penggunaan waktu oleh pekerja didasarkan pada metode pengalokasian biaya berdasarkan aktivitas pada system akuntansi yang sering disebut Activity Based Costing $(A B C)$. Disini kita harus mengkaitkan antara metode $A B C$ dengan sebuah ukuran yang dekat dengan batasan kesuksesan organisasi yaitu-waktu dan bagaimana pimpinan dan staff memanfaatkan waktu tersebut.

Proses evaluasi yang digambarkan disini adalah diarahkan sebagai Activity Based Time Management (ABTM). Dengan ABTM sasaran organisasi dihubungkan dengan sumberdaya waktu yang digunakan oleh organisasi untuk mencapai outcomes yang diinginkan. Ada delapan langkah dalam menerapkan ABTM (William S. Stout:2001):

1. Mengidentifikasi jasa-jasa yang akan dievaluasi

Jasa apakah yang akan disediakan oleh organisasi kemudian jasa yang sudah diidentifikasi bisa menjadi luas atau sangat spesifik .

2. Menunjukkan aktivitas kunci

Aktivitas apa yang harus dilakukan untuk menyediakan jasa tersebut. Dalam ABTM harus dipilih aktivitas yang menduduki peringkat lebih tinggi dari aktivitas apa yang harus dikerjakan.

3. Mengidentifikasi Penggerak Waktu (time drivers)

Penggerak waktu mengukur waktu yang dicurahkan untuk sebuah aktivitas. Misalnya aktivitas menelpon, banyaknya panggilan menunjukkan banyaknya waktu yang dihabiskan.

4. Menentukan penggerak akivitas

Jika penggerak waktu menghubungkan aktivitas dengan waktu, penggerak aktivitas menghubungkan aktivitas dengan outcomes.

5. Menentukan sumberdaya waktu (time resources)

Menentukan berapa banyaknya waktu yang tersedia dalam organisasi. 
6. Mengalokasikan jam untuk aktivitas

Jika jam yang dialokasikan melebihi waktu yang tersedia, maka organisasi akan kehilangan waktu yang tidak mengganti kerugian atau apabila menghubungkan waktu dengan penggerak waktu maka organisasi terlalu bermurah hati/generous.

7. Menghubungkan jam dengan outcomes

Sejak kita mengalokasikan jam pada aktivitas kita dapat mengalokasikan jam pada outcomes.

8. Meramalkan Hasil

Dengan menilai bagaimana waktu dialokasikan untuk mencapai outcomes yang diinginkan akan membantu organisasi dalam membuat keputusan penting mengenai focus organisasi dan kebutuhankebutuhan dimasa depan.

Pengaplikasian ABTM akan menunjukkan bahwa pengalokasian waktu para staff untuk kepentingan organisasi oleh pimpinan, lebih penting daripada outcomes. ABTM juga membantu pimpinan untuk mengevaluasi waktu yang dihabiskan untuk aktivitas khusus. ABTM akan memberikan perspektif baru pada penggunaan sumberdaya dan sebuah alat untuk memaksimalkan kesuksesan organisasi. Yang sangat bermanfaat adalah mengerti dengan lebih baik bagaimana kita menggunakan dan bagaimana kita dapat memaksimalkan hasil pada sumberdaya waktu yang langka dan berharga ini.

Penilaian kinerja menggunakan ukuran waktu yang telah dialokasikan untuk memaksimalkan hasil, perlu dikembangkan dan diterapkan di Indonesia, karena semua organisasi di dunia ini memiliki sumber daya waktu begitu pula organisasi di Indonesia. Selain itu waktu adalah penyama (equalizer) yang sangat baik yang dapat digunakan untuk menilai keefektifan organisasi dalam memanfaatkan waktu yang sangat terbatas dan berharga mahal ini. Misalnya, dengan pengalokasian waktu yang sama pada staff organisasi apakah dapat diperoleh hasil yang sama, lebih besar atau bahkan lebih kecil dibandingkan organisasi lain atau antara staff yang satu dengan lainnya. Kemudian hasil penilaian itu dapat dipakai oleh organisasi untuk memperbaiki atau mempertahankan pengalokasian waktu yang sudah dilakukan agar kinerja organisasi dapat ditingkatkan (Longenecker:1996).

Metode penilaian kinerja organisasi use of time ini juga masih memiliki keterbatasan karena lebih mendorong kinerja individual dalam memanfaatkan waktunya bukan kinerja organisasional. Sehingga penilaian kinerja dilakukan atas dasar perbandingan antara waktu dan outcomes yang dihasilkan anggota organisasi secara individual. 


\section{KESIMPULAN}

Penilaian kinerja sebagai suatu kegiatan MSDM merupakan kegiatan yang penting namun sulit untuk dilakukan. Adanya berbagai mitos dan paradox telah membuat penilaian kinerja sebagai sesuatu yang menakutkan. Kebanyakan pekerja dan pimpinan enggan menerima feedback dari atasan, rekan sejawat maupun penyumbang dana organisasi karena feedback tersebut dianggap dapat mengganggu karir dimasa depan jika tidak sesuai dengan kontribusi yang sudah mereka berikan untuk organisasi.

Sistem Penilaian harus dijalankan, digunakan dan distruktur dengan hati-hati sehingga dapat lebih berguna dan bermanfaat. Sistem penilaian kinerja apapun yang digunakan oleh organisasi tidak menjadi masalah yang penting semua kriteria dan standar penilaian tersebut harus diinformasikan kepada seluruh karyawan dan staff dengan jelas dan harus disesuaikan dengan visi dan misi organisasi sehingga tujuan dari proses evaluasi dapat tercapai yaitu dapat meningkatkan kinerja dan produktivitas pekerja serta organisasi secara keseluruhan. Oleh karena itu penilaian kinerja sebaiknya dilakukan secara efektif, produktif dan consequentional tidak hanya bersifat ceremonial.

Demikian halnya dengan organisasi di Indonesia, seharusnya mulai berjuang keras mengupayakan praktek penilaian kinerja yang bersih dari perilaku KKN antar anggota organisasi. Program penilaian kinerja yang dipilih atau diadopsi hendaknya program penilaian yang dapat menciptakan lingkungan yang kondusif dalam membantu usaha memberantas perilaku KKN dalam penilaian. Sehingga hasil penilaian kinerja tersebut dapat memberikan umpan balik yang positif bagi organisasi dan dapat digunakan untuk melakukan tindak lanjut bagi kegiatan manajemen menuju perbaikan kualitas dan kinerja organisasi.

\section{DAFTAR PUSTAKA}

Antonioni, D., 1996, Designing an effective 360-degree appraisal feedback process, Organizational Dynamics, Autumn 24-38.

Fyock D, Chaterine, 2001, Measuring HR's Impact, HR Magazine.

Flinn, Gillian, 2001, Getting Performance Reviews Right, Journal of Human Resources, 76-78.

Ghorpade, J., and Chen, M.M, 1995, Creating quality -driven performance appraisal system, Academy of Management Executives, 9(1): 32-39.

Longenecker, C.O, \& Gioia, D.A, 1992, The executives appraisal paradox, Academy of Management Executive, 6(2); 18-28. 
Longenecker, C.O, Sims, Jr, H.P, et.all., 1987, Behind the mask: the politic of employee appraisal, Academy of Management Executive, 1(3): 183-193.

Messmer, Max, 2000, Performance Reviews, Society for Human Resource Management, 10-12.

Mc Charty, Julia, 2000, How to conduct Productive Performance Appraisals, Journal of Property Management, September, 23-25.

Nawawi, Hadari, 2000, Manajemen Sumber Daya Manusia untuk bisnis yang kompetitif, Gadjah Mada University Press, Yogyakarta.

Schuler, Randall, S, \& Jackson, Susan, E, 1996, Human Resource Management, $6^{\text {th }}$ ed., West Publishing Company, New York.

Stout, William, D., Jully 2001, Measure Your Use of Time, Non profit World, Vol. 19, No. 4.

Somerick, Nancy, M., Spring 2001, Strategies for Managing an Intern's Performance, Journal of Human Resource, 23-25.

Whie, Richard, June 1998, The High-Performance Organization That Lexington Built, Journal of Human Resource, 18-20. 